\title{
SMART CONTRACT - REVOLUCE V SMLUVNÍM PRÁVU 21. STOLETÍ?
}

\author{
PETRA KRUPIČKOVÁ
}

\begin{abstract}
ABSTRAKT
Článek se zabývá možností uzavření smluv formou kódu (algoritmu) zapsaného $v$ rámci blockchainové databáze. Tyto smlouvy jsou označovány jako smart contract, $i$ když samotný pojem smart contract byl poprvé použit již v roce 1997 na začátku internetové éry před blockchainem pro smlouvy samostatně vykonávající smluvní závazek skrze hardware či software. Blockchainová technologie dokázala ale překlenout některé nedostatky tehdejšího řešení a je předvídáno možné masovější využití možnosti uzavíráni smluv touto formou. Cílem článku je nalézt odpověd', zda lze v rámci českého právního prostředí uzavř́t smlouvu formou kódu, a nastínit možné výzvy, které z této technologické možnosti mohou vyplývat $v$ perspektivě českého práva.
\end{abstract}

\section{KLÍČOVÁ SLOVA}

smart contract, smluvní právo, smlouva, blockchain

\begin{abstract}
This article deals with the possibility of conclusion of contract, which exists in the form of code (algorithm) and are stored in a blockchain. These contracts are called smart contracts, although the term "smart contract" was used for the first time in 1997, at the dawn of the internet age and before blockchain, and designated self-executive contract through software or hardware. Today, the block-

1 Mgr. Petra Krupičková je advokátní koncipientkou v Advokátní kanceláři Pokorný, Wagner \& partneři, s.r.o., kontaktní e-mail je petra.krupickova@gmail.com.
\end{abstract}


chain resolves some issue related to the previous software and hardware contract processing, and it is intended to be applied at mass scale, as way of contract concluding in the form of code. The purpose of this article is to answer whether it is legally possible to conclude smart contract under Czech law, and tackle possible challenges to smart contracting from the Czech perspective.

\section{KEYWORDS}

smart contract, contract law, contract, blockchain

\section{1. ÚVOD}

I když současné rozšíření technologie blockchain (per-to-per decentralizovaná databáze) je spojeno zejména s její vlajkovou lodí - decentralizovanými digitálními kryptoměnami, z nichž nejznámější je bitcoin - a další projekty založené na této technologii jsou ještě na začátku svého možného vývoje. Boom, který tato technologie ale zažívá, je obdivuhodný a každoročně přibývají nové možnosti projekty stavící na této technologii. Jednou z možností, která rovněž využívá potenciálu blockchainu, jsou smlouvy uzavírané skrze algoritmy (počítačové programy).

Základními stavebními kameny těchto počítačových programů, označovaných jako smart contract, jsou jejich vykonatelnost bez vůle smluvních stran skrze podmínky a mechanismy algoritmu - nezměnitelnost zapsaného kódu v blockchainové databázi. Díky těmto vlastnostem smart contracts lze zvýšit transparentnost a snížit náklady v rámci smluvních vztahů, nebot počítačový program sám vykoná smluvní závazek bez nutnosti smluvních stran vydávat možné dodatečné náklady na soudní vymožení splnění. ${ }^{2}$ Lze ale rovněž předpokládat, že tyto specifické parametry této technologie budou představovat výzvu pro právní i soudní praxi. Článek si klade za cíl představit tyto výzvy, i když některá řešení jsou hudbou budoucnosti.

2 RASKIN, M., The Law and Legality of Smart Contracts, str. 315. 


\section{HLEDÁNÍ VÝZNAMU POJMU SMART CONTRACT, ANEB HISTORICKÝ EXKURZ DO VÝVOJE POJMU SMART CONTRACT}

Fenomén smart contract je $\mathrm{v}$ současné době definován různými způsoby, jeho přesný obsah ale není jednoznačný. $V$ širším významu je pojem smart contract vymezován jako „část kódu uloženého na blockchainu, který spouští blockchainové transakce, čte a zapisuje data $v$ blockchainové databázi. “3 $\mathrm{V}$ užším vymezení je pojem smart contract uváděn jako „počítačový program - algoritmus - kterým může samostatně uskutečnit, vymoci, ověřit a omezit výkon dohody “4 či smlouva, která je vykonávána automaticky bez lidského zásahu skrze algoritmus. ${ }^{5}$

Z výše uvedených definic vyplývá, že i když je ve slově smart contract použito anglické slovo označující smlouvu či dohodu, pojmem smart contract jsou v současné době označovány počítačové programy, které často nijak neaspirují na právně závazné jednání. Důvodem tohoto dnešního dezinterpretačního vymezení jsou dle mého názoru zejména projekty typu Ethereum, ${ }^{6}$ které použivají pojem smart contract pro označení všech transakcí zapsaných do jejich blockchainové databáze.

V rámci historické exkurze je ale důležité rovněž upozornit na fakt, že vymezení smart contracts jakožto dohod uzavřených a existujících ve formě softwaru (algoritmu) souvisí se současným technologickým vývojem, zejména s již zmiňovaným blockchainem. Smart contracts však mohou být vykonávány i hardwarově. Právě s primitivním hardwarovým vykonáváním smluvního závazku je spojen nejznámější př́iklad smart contract, který Nick Szabo, autor tohoto pojmu, př̀ definování jeho významu v roce 1997 pou-

3 GREENSPAN, G.,Beware of the Impossible Smart Contract.

${ }^{4}$ SWANSON, T., Great Chain of Numbers: A Guide to Smart Contracts, Smart Property and Trustless Asset Management, str. 16.

5 CLACK Ch. D., ET AL., Smart Contract Templates, str. 2.

6 Projekt Ethereum popsal Vitalik Buterin, jeden ze zakladatelů projektu, jako „blockchain with built-in fully fledged Turing-complete programming language that can be used to create "contracts" that can be used to encode arbitrary state transition functions, allowing users to create any of the systems described above, as well as many others that we have not yet imagined, simply by writing up the logic in few lines of code“. viz. BUTERIN V., Ethereum White Paper, str. 1. 
žil, a to uzavírání kupní smlouvy rámci prodejního automatu. ${ }^{7}$ Př̀i uzavírání kupní smlouvy na zboží v prodejním automatu uzavírá kupující smlouvu s prodejcem, který ve chvíli uzavření smlouvy není přítomen a nemá možnost ovlivnit výkon smlouvy. Přesto $\mathrm{v}$ př́padě, kdy kupující vhodí do automatu požadovanou částku a vybere zboží, tedy akceptuje nabídku prodávajícího, prodejní automat sám provede výkon kupní smlouvy a kupujícímu poskytne požadované zboží. Právě na tomto každodenním příkladu vysvětloval Nick Szabo základní pilír, na němž stojí fungování smart contract, tedy že plnění smlouvy je uskutečněno samostatně bez lidského zásahu. ${ }^{8}$

Szabo ve svých prací ale pracoval s pojmem smart contract především ve spojení $\mathrm{s}$ dohodami, $\mathrm{v}$ rámci kterých jedna strana byla nucena věřit v kredibilitu druhé strany. Tento problém následně pomohla překlenout technologie blockchain, která přinesla do vnímání uzavírání smluv skrze počítačové programy výraznou revoluci.

Samotnou technologii blockchain lze shrnout jako databázi dat jednotlivých transakcí sdílenou $\mathrm{v}$ rámci per-to-per sítě a zajištující stálost dat a koncensus jednotlivých uživatelů při schvalování každé transakce. ${ }^{9} \mathrm{Na}$ základě tohoto mechanismu byla vytvořena důvěryhodná decentralizovaná databáze bez nutnosti centrální autority. $Z$ důvodu důvěryhodnosti databáze neumožňuje mechanismus blockchainu změnit či přepsat digitální záznam zapsaný a autorizovaný $\mathrm{v}$ rámci databáze. Blockchainová technologie tak přinesla do uzavírání smluv revoluci $\mathrm{v}$ jejich transparentnosti, důvěryhodnosti a zejména nezměnitelnost smluv uzavřených skrze počítačový program.

Lze tedy shrnout, že hledání univerzální definice pojmu smart contract je v současné době, kdy je tento pojem používán pro různé formy, nemožné. Pro účely tohoto článku se budu zabývat pouze částí smart contracts zapsaných na blockchainovém protokolu, které představují dohodu dvou nebo více osob, jejichž

\footnotetext{
7 SZABO, N., Smart Contracts: Formalizing and Securing Relationships.

8 SZABO, N., Smart Contracts: Formalizing and Securing Relationships.

9 BACK A. ET AL., Enabling blockchain innovations through pegged sidechains, str. 4.
} 
1. vykonatelnost je uskutečněna bez vůle smluvních stran skrze podmínky a mechanismy algoritmu;

2. nezměnitelnost zapsaného kódu je zajištěna per-to-per decentralizovanou databází blockchain;

3. digitální existence smluvního závazku v podobě počítačového programu (algoritmu) je vyjádřena $\mathrm{v}$ programovacím jazyce $\mathrm{v}$ kódu.

\section{UZAVŘENÍ SMLOUVY FORMOU POČÍTAČOVÉHO KÓDU}

S ohledem na zásadu bezformálnosti vyplývající z ust. § 559 NOZ nepředstavuje uzavření smlouvy prostřednictvím počítačového kódu $\mathrm{v}$ českém právním prostředí významný problém. V rámci smluv uzavíraných skrze algoritmy je ale dle mého názoru velmi důležitá shoda smluvních stran na uzavření smlouvy touto formou. $\mathrm{V}$ př́padě, kdy by nebyla shoda smluvních stran na uzavření smlouvy formou algoritmu, smlouva by vznikla ve smyslu ust. § 1725 NOZ okamžikem shody na jejím obsahu, který nemusí být totožný s okamžikem naprogramování algoritmu a mohlo by tak dojít $\mathrm{k}$ uzavření smlouvy jinou formou, např. ústní formou s následným vykonáním smlouvy formou kódu.

V situaci, kdy by smlouva byla uzavřena jinou formou s následným vykonáním skrze kód, by došlo nejenom k změně formy smlouvy, ale zejména takováto situace výrazně ovlivňuje možnost dodatečné změny smlouvy. $\mathrm{S}$ ohledem na zapsání smart contracts $\mathrm{v}$ rámci blockchainové databáze, $\mathrm{v}$ níž jsou zápisy nezměnitelné, totiž po uzavření smlouvy zapsané do této databáze nelze obsah smlouvy změnit, i kdyby zde byla vůle obou stran ke změně takové smlouvy. Oproti tomu $\mathrm{v}$ případě, kdy algoritmus představuje pouze způsob plnění smluvního závazku, mohou smluvní strany obsah smlouvy dodatečně změnit, nezměnitelný bude pouze zápis plnění smluvního závazku. Forma právního jednání uskutečněného $\mathrm{v}$ rámci smart contract tak může výrazně ovlivnit účinky smlouvy. 


\section{PÍSEMNÁ FORMA SMLUV UZAVŘENÝCH PROSTŘEDNICTVÍM KÓDU}

Smart contract jsou uzavřeny ve virtuální (elektronické) podobě. Otázku ale představuje, zda uzavíráním smluv skrze počítačový program lze splnit požadavky pro písemnou formu elektronicky učiněného právního jednání ve smyslu ust. $§ 561$ ve spojení s ust. $§ 562$ NOZ. ${ }^{10}$ Pro splnění požadavků dle těchto ustanovení musí smlouva uzavřená kódem být učiněna elektronickým prostředkem umožňujícím i) zachycení obsahu právního jednání, ii) určení jednající osoby a iii) podpis smlouvy. Je tedy nutné položit si otázku, zda kódy mohou zachycovat obsah právního jednání či zda umožňuje anonymní blockchainová technologie jednoznačné určení osoby. Specifickou kategorií je pak možná nejtěžší otázka zabývající se naplněním zákonných podmínek pro elektronické podpisy. Rozporuplné tak dle mého názoru mohou při uzavírání smluv prostřednictvím kódu být všechny předpoklady vyplývající z ust. § 561 ve spojení s ust. § 562 NOZ.

Smart contracts jakožto kódy jsou sepsány $\mathrm{v}$ programovacím jazyku s velmi specifickou syntaxí a sémantikou. ${ }^{11}$ Obsah těchto smluv je čitelný pouze skupině lidí, kteří rozumí konkrétnímu programovacímu jazyku. Pro platnost písemného jednání ale není rozhodné, jaký jazyk bude v rámci písemné formy použit. ${ }^{12}$ Tyto kódy tak zachycují obsah právního jednání (i když obsah právního jednání je zapsán v programovacím jazyce). První požadavek je dle mého názoru u smluv uzavřených prostřednictvím kódu naplněn.

10 Problematika dodržení písemné formy smart contract je kruciální například u rozhodčích doložek sjednávaných dle $\S 3$ odst. 3 zákonač. 216/1994 Sb., o rozhodčím řízení a výkonu rozhodčích nálezů, ve znění pozdějších předpisů. Rozhodčí doložky samozřejmě nejsou nutností a v rámci smart contract představují velmi okrajovou otázku, mohou ale pomoci překlenout hned několik z hlavních výzev spojených se smart contracts. Smart contracts jsou kódy sepsanými $v$ programovacím jazyce zapsanými na nově velmi dynamicky se vyvíjející technologii blockchain, pro jejichž porozumění je nutná určitá znalost této problematiky. Rozhodčí soudy zabývající se touto problematikou tak mohou být v budoucnu dle mého názoru flexibilnějším technologicky zdatnějším protipólem $\mathrm{k}$ soudnímu řízení.

11 SAVELYEV, A., Contract Law 2.0: «Smart» Contracts As the Beginning of the End of Classic Contract Law, str. 13.

12 LAVICKÝ, P. a kol., Občanský zákoník I. Obecná část (§ 1-654), str. 2021. 
Problematičtější část může ale představovat identifikace smluvních stran. Blockchainová technologie je totiž založena na kryptografických záznamech, zašifrovaných pomocí hashovacích funkcí a zajištující anonymitu uživatelů sítě. Zašifrované jsou rovněž privátní a veřejné klíče sloužící k autorizaci jednotlivých transakcí v rámci blockchainové databáze. Veřejné klíče přitom slouží k identifikaci osoby v rámci blockchainové databáze; každý uživatel veřejně vystupuje $v$ rámci jednotlivých transakcí pod konkrétním veřejným klíčem (i když není vyloučeno, aby měl jeden uživatel více veřejných klíčů). I když veřejný klíč není ve formě standardní identifikace osoby představující její jméno prríjmení, veřejný klíč je přiřazený pouze jednomu konkrétnímu uživateli, nebot pod veřejným klíčem může vystupovat pouze držitel privátního klíče. S ohledem na technologický vývoj se tedy domnívám, že nelze již v 21. století trvat na nutnosti jednoznačného určení osoby pomocí jejího jména a přímení, ale bude nutné reflektovat rovněž skutečnost, že jednotlivé osoby budou vystupovat v rámci právních vztahů i pod údaji, ze kterých nebude jejich jméno a př́ijmení jednoznačně zřejmé, ale které i přesto umožňují jednoznačné určení této osoby. Dle mého názoru tedy veřejný klíč poskytuje dostatečnou identifikaci konkrétní osoby a i druhá podmínka vyplývající z ust. § 562 odst. 1 NOZ je naplněna.

V souvislosti s identifikací osoby požaduje rovněž zákonná úprava poslední náležitost písemné formy ve formě podpisu, který je pro elektronické dokumenty upraven v zákoně č. 297/2016 Sb., o službách vytvářejících důvěru pro elektronické transakce, který v souladu s eIDAS ${ }^{13}$ umožňuje při smluvních vztazích použití všech typů elektronických podpisů, ${ }^{14}$ zejména zaručeného elektronického podpisu. ${ }^{15}$ Zaručený elektronický podpis musí v souladu s eIDAS splňovat následující požadavky i) je jednoznačně spojen s podepisující osobou, ii) umožňuje identifikaci podepisující osoby, iii) je vy-

13 Nařízení Evropského parlamentu a Rady (EU)č. 910/2014 ze dne 23. července 2014 o elektronické identifikaci a službách vytvářejících důvěru pro elektronické transakce na vnitřním trhu a zrušení směrnice 1999/93/ES.

14 Viz důvodová zpráva k zákonu č. 297/2016 Sb., službách vytvářejících důvěru pro elektronické transakce.

15 Viz závěr Polčáka, že jen zaručený elektronický podpis plní obdobné základní funkce listinného podpisu, POLČÁK, R., Praxe elektronických dokumentů, str. 56. 
tvořen pomocí dat pro vytváření elektronických podpisů, která podepisující osoba může s vysokou úrovní důvěry použít pod svou výhradní kontrolou a iv) je $\mathrm{k}$ datům, která jsou tímto podpisem podepsána, připojen takovým způsobem, že je možné zjistit jakoukoliv následnou změnu dat.

$\mathrm{V}$ případě smart contracts je vyžadováno při nahrání a autorizaci v rámci blockchainové databáze použití privátního a veřejného klíče, jak je uvedeno výše. Zápis uskutečněný bez použití privátního a veřejného klíče je síti automaticky odmítnut. Veřejný klíč přitom umožňuje veřejnou identifikaci konkrétního uživatele. Domnívám se tedy, že veřejný klíč je jednoznačně spojen s jeho držitelem a umožňuje identifikaci kontrahenta (i. a ii. podmínka). Vstupovat do transakcích pod veřejným klíčem ale může pouze držitel privátního klíče, který jediný zná unikátní privátní klíč. Ze skutečnosti, že s veřejným klíčem může nakládat pouze držitel privátního klíče, vyplývá, že nad veřejným klíčem vykonává kontrolu pouze jeho držitel (iii. podmínka). Data nahraná do blockchainové databáze dále nelze po nahrání a podepsání v blockchainové databází změnit (iv. podmínka). Mám tedy zato, že privátní i veřejný klič naplňují všechny podmínky vyžadující pro zaručený elektronický podpis.

Ze splnění výše uvedených podmínek tedy lze dovodit, že smart contract mohou naplnit písemnou formu pro elektronicky uskutečněné právní jednání ve smyslu ust. $\S 561$ ve spojení s ust. § 562 NOZ. I když tedy lze považovat smart contract za specifickou formu uzavírání smlouvy, která s ohledem na volnost smluvních stran při volbě formy právního jednání může být využita, může smart contract naplnit i požadavky písemné formy.

\section{SMART CONTRACT JAKO VÝZVA PRO PRÁVNÍ I SOUDNÍ PRAXI?}

Smart contracts nejsou ale pouze speciální formou uzavření smlouvy, která může naplnit podmínky pro písemnou formu, smart contracts jsou zejména počítačové programy, které bez vůle smluvních stran vykonávají smluvní závazek a jejichž kód je nezměnitelně zapsán v blockchainu. Z nezměnitelnosti zapsaného kódu $\mathrm{v}$ rámci per-to-per decentralizované databáze blockchain a vykonatelnosti závazku bez vůle smluvních stran vy- 
plývají hlavní výzvy pro právní praxi. Závazek, k jehož plnění se smluvní strany ve smlouvě zavážou v rámci smart contract, je po nahrání do blockchainové databáze nezměnitelně vykonán bez možnosti smluvních stran změnit si následně ${ }^{16}$ obsah závazku dle ust. § 1901 a násl. NOZ. Zásada pacta sunt servanda je u těchto smluv dovedena do technologické dokonalosti. $^{17}$

Tato skutečnost dokonce vedla Savelyeva ve své práci k úvaze, zda lze stále dovozovat $\mathrm{v}$ rámci smart contract existenci závazku ve smyslu římskoprávní a kontinentální jurisprudence, ${ }^{18}$ nebot smluvní závazek je vztah mezi dvěma a více stranami, ze kterého stranám v budoucnosti vznikají práva a povinnosti. ${ }^{19} \mathrm{~V}$ rámci smart contracts je ale smluvní povinnost vykonána počítačovým programem bez vưle smluvních stran. Savelyev si tak ve své práci pokládá otázku, zda z tohoto důvodu představují smart contracts ještě smlouvu. I když si na ni následně odpovídá kladně, považuje smart contracts za jednu z možných změn chápání závazku smluvního vztahu.

I když závazek ve smyslu budoucího plnění poskytovaného jednotlivými smluvními stranami je $\mathrm{v}$ rámci smart contract nahrazen plněním zajištěným algoritmem, při uzavírání smlouvy či dohody je důležitý zejména konsenzus smluvních stran. ${ }^{20}$ Přestože je plnění smlouvy uskutečněno $\mathrm{v}$ rámci smart contract bez vůle smluvních stran, je zde vůle smluvních stran zřídit mezi sebou závazek a řídit se obsahem smlouvy. ${ }^{21}$ Právě dostatečně určitý konsenzus mezi smluvními stranami je základní požadavek českého zákonodárci pro vznik smlouvy. ${ }^{22} \mathrm{~V}$ rámci smart contracts tak i přes neutrální

\footnotetext{
16 Pokud si smluvní strany v rámci kódu neupraví jiné parametry.

17 SAVELYEV, A., Contract Law 2.0: «Smart» Contracts As the Beginning of the End of Classic Contract Law, str. 18.

18 SAVELYEV, A., Contract Law 2.0: «Smart» Contracts As the Beginning of the End of Classic Contract Law, str. 17.

19 SAVELYEV, A., Contract Law 2.0: «Smart» Contracts As the Beginning of the End of Classic Contract Law, str. 18.

${ }^{20}$ HULMÁK, M. a kol.: Občanský zákoník V. Závazkové právo. Obecná část (§ 1721-2054), str. 19.

${ }^{21}$ Viz $§ 1724$ odst. 1 NOZ.
} 
plnění smluvního závazku počítačovým programem s ohledem na tuto skutečnost vzniká smlouva.

Skutečnost, že počítačový program pracuje neutrálně a nezměnitelně na bázi, když A stane se B, představuje hlavní přednost smart contracts. Dochází tím ke snížení nákladů na vymožení plnění jednotlivých smluvních stran v př́padě prodlení. Počítačový program pracuje čistě na bázi předem daných nezměnitelných podmínek, které minimalizují možnost smluvních stran dostat se do prodlení. Splnění závazku mimo vůli smluvních či třetích $\operatorname{stran}^{23}$ ale bude pravděpodobně představovat výzvu pro soudní praxi, jejichž dnešní úkol spočívá především ve vynucování splnění závazku. Tento úkol se $\mathrm{v}$ př́ípadě smart contracts posune i do rozhodování o platnosti smluv, které již byly splněny či jejich plnění v době trvání soudu bude probíhat. ${ }^{24}$ Soudy budou zřejmě nuceny zaujmout postoj vưči smlouvám, jež nelze zrušit ani změnit, přes jejich možnou nezákonnost či zdánlivost.

Existence smluvních závazků a vykonatelnost byla do současnosti přitom otázkou právní úpravy. Pouze právní jednání, které odpovídá zákonným požadavkům dobrým mravů, vyvolává právní následky. ${ }^{25}$ Právní jednání, které se zjevně přičí zákonu nebo dobrým mravům, je neplatné a hledí se na něj, jako kdyby nevzniklo. ${ }^{26}$ Počítačový program však splní předem nadefinovaný závazek pokaždé, bez ohledu na (ne)planost tohoto jednání a (ne)vyvolání právní následků. Právní řád a zejména soudní praxe tak bude muset $\mathrm{v}$ budoucnu reagovat na skutečnost, že zde existuje vykonaný smluvní závazek, jenž byl fakticky vykonán z neplatného či zdánlivého právního jednání. ${ }^{27}$

S ohledem na některá specifika smart contracts může tato svébytná forma uzavírání smluv představovat $\mathrm{v}$ některých oblastech výzvu pro právní a

${ }^{22}$ HULMÁK, M. a kol.: Občanský zákoník V. Závazkové právo. Obecná část (§ 1721-2054), str. 19.

${ }^{23}$ SAVELYEV, A.r, Contract Law 2.0: «Smart» Contracts As the Beginning of the End of Classic Contract Law, str. 15.

${ }^{24}$ RASKIN, M., The Law and Legality of Smart Contracts, str. 315.

${ }^{25}$ Viz ust. § 545 ve spojení s ust. § 547 NOZ.

${ }^{26}$ Viz. ust. § 580 odst. 1 ve spujení s ust. § 588 NOZ.

${ }^{27}$ RASKIN, M., The Law of Smart Contracts (September 22, 2016). Georgetown Technology Review, Forthcoming, str. 19. 
soudní praxi. Dle mého osobního názoru smart contracts ale nebudou představovat výraznou revoluci ve smluvním právu. Velká většina dnes uzavíraných smluv totiž nezajištuje pouze jednoduchou úlohu, když A stane se B, ale obsahují často komplexní úpravu řešení v budoucnu možná vzniklých skutečností, pro které je často důležitý mnohem bohatší jazyk, než jaký poskytuje programovací jazyk. Budoucnost smart contracts tak lze předpokládat $\mathrm{v}$ jednodušších smlouvách.

\section{ZÁVĚR}

V článku jsem předestřela možnost uzavřít smlouvu počítačovým programem, který je nahrán rámci decentralizované databáze blockchain, tzv. smart contract. Tato technologie umožňuje uzavřít smlouvu pomocí kódu, který je po nahrání na důvěryhodnou blockchainovou databázi nezměnitelně vykonatelný bez vůle smluvních stran. Vykonatelnost smlouvy bez vůle smluvních stran tak snižuje možné dodatečné náklady na vymožení smluvního plnění, nebot zásada pacta sunt servanda zde platí bezmezně. Smluvní strany si ale nemohou smluvní podmínky měnit ani v případě vůle smluvních stran či při podstatné změně okolností. Problém představuje rovněž uzavření smart contract s nezákonným plnění či za podmínek, které by způsobovaly neplatnost či zdánlivost právního jednání. Smart contracts jako počítačové programy, totiž pracují nezávisle a vykonají smluvní závazek i přes jejich nesoulad s právní úpravou. Všechny tyto skutečnosti dle mého názoru budou představovat možnou výzvu pro soudní i právní praxi. Domnívám se proto, že bude zajímavé sledovat, zda se skutečně smart contracts stanou alternativou ke „klasické“ smlouvě a jakým zpo̊sobem se právní i soudní praxe s výzvami z této technologie vyplývajícími vyrovná, pokud vyvstanou.

\section{SEZNAM LITERATURY}

\subsection{LITERATURA}

[1] BACK, Adam a kol. Enabling blockchain innovations through pegged sidechains [online]. Blockstream, 22. 10. 2014 [cit. 17. 3. 2017]. Dostupné z: http://www.blockstream.com/sidechains.pdf 
[2] BUTERIN, Vitalik. Ethereum White Paper, next generation smart contract \& decentralized application platform [online]. [cit. 25. 3. 2017]. Dostupné z: http://www.theblockchain.com/docs/Ethereum_white_paper-a_next_generation_smart_contract_and_decentralized_application_platform-vitalik-buterin.pdf

[3] CLACK, Christopher D. BAKSHI, Vikram A. BRAINE. Lee. Smart Contract Templates [online]. Barclays Bank PLC 2016 [cit. 1. 2. 2017]. Dostupné http://arxiv.org/pdf/1608.00771v2.pdf

[4] GREENSPAN, Gideon. Beware of the Impossible Smart Contract, [online]. MultiChain, 12 dubna 2016 [cit. 10. 12. 2016]. Dostupné z: http://www.multichain.com/blog/2016/04/beware-impossible-smart-contract/

[5] HULMÁK, Milan. a kol. Občanský zákoník V. Závazkové právo. Obecná část (§ 1721-2054). Komentář. 1. vydání. Praha: C. H. Beck, 2014, 1335 s. ISBN 978-80-7400-535-0.

[6] LAVICKÝ, Petr. a kol.: Občanský zákoník I. Obecná část (§ 1-654). Komentář. 1. vydání, Praha: C. H. Beck, 2014, 2400 s. ISBN 978-80-7400-529-9.

[7] POLČÁK, Radim. Praxe elektronických dokumentů. Bulletin advokacie, Praha: Česká advokátní komora, 2011, 7-8, s. 53-61. ISSN 1210-6348.

[8] RASKIN, Max. The Law and Legality of Smart Contracts [online]. 1 Georgetown Law Technology Review 304 (2017). [cit. 16. 5. 2017] Dostupné z: https://ssrn.com/abstract $=2959166$

[9] SAVELYEV, Alexander. Contract Law 2.0: «Smart» Contracts As the Beginning of the End of Classic Contract Law [online].Higher School of Economics Research Paper No. WP BRP 71/LAW/2016. 14. 12. 2016 [cit. 16. 3. 2017]. Dostupné z: https://ssrn.com/abstract $=2885241$

[10] SWANSON, Tim. Great Chain of Numbers: A Guide to Smart Contracts, Smart Property and Trustless Asset Management, [online]. [cit. 16. 2. 2017]. Dostupné z: https://s3-us-west2. amazonaws.com/chainbook/Great + Chain + of + Numbers + A + Guide + to + Smart + Contract s, + Smart + Property + and + Trustless + Asset + Management + - + Tim + Swanson.pdf

[11] SZABO, Nick. Smart Contracts: Formalizing and Securing Relationships on Public [online]. Networks, First Monday, Volume 2, Number 9, 1. 9.1997 [cit. 24. 1. 2017]. Dostupné z: http://journals.uic.edu/ojs/index.php/fm/article/view/548/469

\subsection{PRÁVNÍ PŘEDPISY}

[12] Důvodová zpráva k zákonuč. 297/2016 Sb., o službách vytvářejících důvěru pro elektronické transakce.

[13] Nařízení Evropského parlamentu a Rady (EU)č. 910/2014 ze dne 23. července 2014 o elektronické identifikaci a službách vytvářejících důvěru pro elektronické transakce na vnitřním trhu a o zrušení směrnice 1999/93/ES.

[14] Zákon č. 216/1994 Sb., o rozhodčím řízení a o výkonu rozhodčích nálezů, ve znění pozdějších předpisů.

[15] Zákon č. 297/2016 Sb., o službách vytvářejících důvěru pro elektronické transakce. 
[16] Zákon č. 89/2012 Sb., občanský zákoník, ve znění pozdějších předpisů.

Toto dílo lze užít v souladu s licenčními podmínkami Creative Commons BY-SA 4.0 International (http://creativecommons.org/licenses/by-sa/4.0/legalcode). 
